\title{
Susceptibility and pathological consequences of catla, Catla catla (Hamilton) experimentally infected with Edwardsiella tarda
}

\author{
Thongam Bidya Devi, T. Jawahar Abraham, Dibyendu Kamilya
}

Received - 30 January 2016/Accepted - 30 August 2016. Published online: 31 December 2016; @Inland Fisheries Institute in Olsztyn, Poland Citation: Devi T.B., Abraham T.J., Kamilya D. 2016 - Susceptibility and pathological consequences of catla, Catla catla (Hamilton) experimentally infected with Edwardsiella tarda - Arch. Pol. Fish. 24: 209-217.

\begin{abstract}
The present study tested the susceptibility and pathological changes of catla, Catla catla (Hamilton) infected with Edwardsiella tarda (ET-PG-29). The bacterium was isolated from the kidney of a diseased pangas catfish. To determine the median lethal dose $\left(\mathrm{LD}_{50}\right), C$. catla were challenged with this bacterium $\left(10^{8}-10^{3} \mathrm{CFU} \mathrm{ml}^{-1}\right)$, and the $\mathrm{LD}_{50}$ was calculated as $10^{5.5} \mathrm{CFU} \mathrm{ml}^{-1}$. Another set of healthy C. catla were injected intraperitoneally with the $\mathrm{LD}_{50}$ dose to induce edwardsiellosis. The clinical signs of the infected $C$. catla were observed and recorded. Tissues such as kidney, liver, intestine, heart, and gill from the infected fish with clinical signs of edwardsiellosis were used for histopathology. The clinical and gross signs were first visible at $1 \mathrm{~d}$ post-injection, and the infected fish showed typical signs of hemorrhagic septicemia. The most striking histopathological features were found in the kidney which showed multi-focal necrosis with the formation of granuloma indicating an inflammatory response against the pathogen. The intestine displayed goblet cell hyperplasia, the liver showed hydropic degeneration with hyperemic central veins, and there was inflammation of gill lamellae and cardiac myositis associated with leucocyte infiltration. Collectively, the results confirmed
\end{abstract}

T.B. Devi, D. Kamilya [ $\equiv]$

Department of Fish Health and Environment

College of Fisheries, Central Agricultural University

Lembucherra, Tripura (w) - 799210, Tripura, India

\section{T.J. Abraham}

Department of Fishery Pathology and Microbiology, Faculty of Fishery Sciences,

West Bengal University of Animal and Fishery Sciences

5 - Budherhat Road, Chakgaria, P. O - Panchasayar

Kolkata - 700094, West Bengal, India the susceptibility of $C$. catla to $E$. tarda infection and that this bacterium is a threat to $C$. catla in aquaculture practices.

Keywords: Edwardsiellosis, Catla, pathology, granulomatous inflammation

\section{Introduction}

Edwardsiellosis is a common fish disease caused by the bacterium Edwardsiella tarda, a facultative anaerobic Gram negative motile rod belonging to the family enterobacteriaceae (Plumb 1999). This bacterium has a broad host range, infecting a wide range of reptiles, birds, and mammals, in addition to fish (Rao et al. 2001). E. tarda is an opportunistic pathogen and environmental stresses such as overcrowding, malnutrition, sudden changes of water temperature, $\mathrm{pH}$, and fluctuations in dissolved oxygen contribute to the onset of the infection (Plumb 1993). Infection by this bacterium can affect all fish life stages resulting in massive mortalities and associated economic losses (Mohanty and Sahoo 2007). Edwardsiellosis, which causes hemorrhagic septicemia in different cultured fishes, has been reported in different parts of the world including India (Herman and Bullock 1986, Mohanty and Sahoo 2007, Xiao et al. 2009, Shetty et al. 2014). 
The cultivation of Indian major carps, such as catla, Catla catla (Hamilton), rohu, Labeo rohita (Hamilton), and mrigal, Cirrhinus mrigala (Hamilton), is the mainstay of Indian aquaculture that contributes more than $80 \%$ to the total aquaculture production in the country (Lakshman et al. 2015). Besides India, these species are also widely cultivated in several neighboring countries (Reddy 1999). C. catla has been reported to be infected naturally by this bacterium (Swain and Nayak 2003) as well as by experimental infection (Mohanty and Sahoo 2010, Devi et al. 2012). Although a large-scale outbreak of edwardsiellosis has not been reported, the bacterium is a potential threat to the successful farming of catla owing to the high susceptibility of $C$. catla to this pathogen.

Table 1

Formulation and proximate composition of the diet

\begin{tabular}{|c|c|}
\hline Ingredients and proximate composition & $\begin{array}{l}\text { Dry matter } \\
(\%)\end{array}$ \\
\hline \multicolumn{2}{|l|}{ Ingredients } \\
\hline Mustard oil cake $^{\mathrm{a}}$ & 18 \\
\hline Rice bran ${ }^{a}$ & 10 \\
\hline Fish meal $^{\mathrm{a}}$ & 24 \\
\hline Soybean meal $^{\mathrm{a}}$ & 20 \\
\hline Corn $^{\mathrm{a}}$ & 25 \\
\hline Vitamin mineral premix ${ }^{b}$ & 2.6 \\
\hline Carboxy Methyl Cellulose $^{\mathrm{c}}$ & 0.4 \\
\hline \multicolumn{2}{|l|}{ Proximate composition } \\
\hline Crude protein & 32.12 \\
\hline Moisture & 6.11 \\
\hline Crude lipid & 9.14 \\
\hline Ash & 11.48 \\
\hline Crude fibre & 14.28 \\
\hline Nitrogen free extract (digestible carbohydrate) & 26.87 \\
\hline \multicolumn{2}{|c|}{$\begin{array}{l}{ }^{\mathrm{a}} \text { Purchased from local dealers, Agartala, India } \\
{ }^{\mathrm{b}} \text { Vitamin mineral mixture (KALVIMIN FORTE) (Quantity per } \\
2.5 \mathrm{~kg} \text { ). Vitamin-A: 50,00,000 IU; Vitamin-B } 2: 2.0 \mathrm{gm} \text {; } \\
\text { Vitamin- } \mathrm{B}_{12}: 6.0 \mathrm{mg} \text {; Vitamin- } \mathrm{D}_{3}: 10,00,000 \mathrm{IU} \text {; Calcium } \\
\text { Pantotherate: } 4.0 \mathrm{gm} \text {; Calcium: } 800 \mathrm{gm} \text {; Phosphorus: } 150 \\
\text { gm; Manganese: } 27.5 \mathrm{gm} \text {; Iodine: } 1.0 \mathrm{gm} \text {; Iron: } 7.5 \mathrm{gm} \text {; Zinc: } \\
15.0 \text { gm; Copper: } 2.0 \mathrm{gm} \\
{ }^{\mathrm{c}} \text { Carboxymethyl Cellulose (Himedia, India) }\end{array}$} \\
\hline
\end{tabular}

Pathological changes caused through natural or experimental infection by this bacterium have been studied in different fish species, but not in C. catla. In fish, this bacterium not only causes extensive skin lesions but several internal organs such as the liver, kidneys, and spleen are also affected (Mohanty and Sahoo 2007). When a pathogen is able to penetrate the anatomical barriers of a host and causes infection, a non-specific inflammatory response is triggered initially. The inflammatory reaction to E. tarda infection varies among different fish species and can be characterized by histopathology. In some fish, the inflammatory response to $E$. tarda has been described as suppurative, whereas in others, it is granulomatous (Miyazaki and Kaige 1985). There is, however, no report regarding the type of inflammatory response that occurs in catla infected with $E$. tarda. Thus, the present investigation was undertaken to elucidate the susceptibility and pathological consequences, especially the inflammatory reaction, in $C$. catla that were experimentally infected with $E$. tarda through intraperitoneal injection.

\section{Materials and methods}

\section{Collection of fish and maintenance}

Three hundred C. catla with body weights of 39.60 $\pm 3.06 \mathrm{~g}$ and without any visible clinical signs were obtained from our college farm located in Lembucherra, West Tripura, India and stocked in 10001 indoor circular tanks supplied with dechlorinated tap water. The fish were free of $E$. tarda and parasitic infections which were confirmed by kidney cultures of randomly sampled fish, indirect ELISA for E. tarda antibody determination, and microscopy. The fish were acclimatized at the ambient temperature $\left(28 \pm 1^{\circ} \mathrm{C}\right)$ for three weeks with aeration and were fed twice daily with a pelleted diet prepared using locally available ingredients (Table 1) at the rate of $5 \%$ of body weight. The optimum physicochemical water parameters were maintained throughout the period of the experiment by daily 
water exchange (up to $50 \%$ ) to remove waste feed and fecal material.

\section{Edwardsiella tarda}

The pathogenic strain of E. tarda (ET-PG-29) used to infect the $C$. catla was isolated from the kidney of a diseased pangas catfish, Pangasius pangasius (Hamilton), during an outbreak. The biochemical characterization of the strain was done using conventional biochemical tests (MacFaddin 1980, Austin and Austin 2007), a Rapid HiAssorted ${ }^{\mathrm{TM}}$ biochemical test kit (HiMedia, Mumbai, India), and an automated bacterial identification system (VITEK 2-Compact, BioMerieux, France). Hemolytic assays were done by spot inoculating the young culture of $E$. tarda from a tryptone soya agar (TSA; HiMedia) plate on to a sheep blood agar plate (HiMedia) and incubated at $30^{\circ} \mathrm{C}$ for $24 \mathrm{~h}$. The strain was subcultured on TSA at $30^{\circ} \mathrm{C}$ four times at 15 day intervals. Before being used in the challenge study, the strain was injected intraperitoneally into $C$. catla and an isolate from kidney, grown on E. ictaluri agar (Shotts and Waltman II 1990), was purified on TSA. The purified strain was confirmed as E. tarda according to the identification keys of Fisheries and Oceans Canada (2004), and it was used immediately.

\section{Determination of Median Lethal Dose $\left(\mathrm{LD}_{50}\right)$ of $E$. tarda}

To determine the $\mathrm{LD}_{50}$ of $E$. tarda, seven treatments (for six bacterial doses and one control) were replicated three times each. The treatments were allocated randomly in 21 tanks (500 l). Eight fish were stocked into each tank and were acclimatized (as described earlier) for one week.

An overnight culture of E. tarda, grown in tryptone soya broth (HiMedia) was centrifuged at $5000 \mathrm{rpm}$ for $10 \mathrm{~min}$ at $4^{\circ} \mathrm{C}$, washed twice in physiological saline $(0.85 \%$ sodium chloride), and then resuspended in the same solution to achieve a concentration of $10^{9} \mathrm{CFU} \mathrm{ml}^{-1}$. The number of cells in suspension was determined by spread plating on TSA and incubating at $30^{\circ} \mathrm{C}$ for $24 \mathrm{~h}$. The bacterial suspension was subjected to ten-fold serial dilutions to obtain concentrations ranging from $10^{8}$ to $10^{3}$ CFU ml ${ }^{-1}$. Two hundred microliters of each dilution was injected intraperitoneally into each of the fish. The control fish received $200 \mu \mathrm{l}$ of sterile physiological saline instead of the bacterial suspension. The fish were reared at the ambient temperature $(28 \pm$ $1^{\circ} \mathrm{C}$ ) and fed daily with the pelleted feed as described earlier. The mortalities were recorded daily for three weeks. Dead fish were removed from the tank daily. Based on the mortality data, the $\mathrm{LD}_{50}$ of E. tarda was calculated with the method described by Reed and Muench (1938).

\section{Experimental infection}

Experimental infection was performed in nine 5001 tanks containing ten fish each as described in our previous publication (Devi et al. 2012). Briefly, fish in six tanks were anesthetized with MS-222 (100 mg $\mathrm{l}^{-1}$; HiMedia) and injected intraperitoneally $(0.2 \mathrm{ml}$ fish $\left.^{-1}\right)$ with the $\mathrm{LD}_{50}$ dose of E. tarda $\left(10^{5.5} \mathrm{CFU}\right.$ $\mathrm{ml}^{-1}$ ) as calculated previously. The anesthetized control fish were injected with $0.2 \mathrm{ml}$ of physiological saline intraperitoneally. The fish were maintained as described previously. Clinical and gross signs of the injected fish were recorded. To confirm the cause of infection, bacteria were recovered from the kidneys of the challenged fish on EIA and their identities were presumptively confirmed by biochemical reactions as described in the identification keys (Fisheries and Oceans Canada 2004).

\section{Histopathology}

The fish used for histopathology were sampled every day for four days post-injection (DPI). On each sampling date, three infected fish with clinical signs of edwardsiellosis and also control fish were collected randomly for histopathology. The fish sampled were euthanized with an overdose of MS-222, immediately dissected, and different tissues such as the 
kidney, liver, intestine, heart, and gill were fixed in $10 \%$ buffered formalin. The fixed tissues were processed according to standard histopathological techniques and the tissue sections were stained with hematoxylin and eosin (H\&E) (Presnell and Schreibman 1997).

\section{Results}

\section{Bacterial characterization}

The strain isolated was a Gram-negative, fermentative, motile short rod, and was negative for cytochrome-oxidase, Voges Proskauer reaction, and ONPG, but it was positive for hydrogen sulphide production. It was a $\gamma$-hemolytic (non-hemolytic) strain as assessed on sheep blood agar. Phenotypic characterization and BioMerieux VITEK 2 - Compact data both confirmed that the strain was E. tarda.

\section{Median Lethal Dose $\left(\mathrm{LD}_{50}\right)$ of E. tarda}

Catla mortality after the challenge occurred continuously, and it increased with increasing bacterial concentrations except at the lowest dose $\left(10^{3} \mathrm{CFU}\right.$ $\mathrm{ml}^{-1}$ ) (Fig. 1). The mortality percentage corresponding to different bacterial doses $\left(10^{8}-10^{3} \mathrm{CFU} \mathrm{ml}^{-1}\right)$ were $100,87.5,62.5,37.5,12.5$ and $0 \%$, respectively and the percent of fish with external clinical signs were $100,100,100,87.5,62.5$, and $37.5 \%$, respectively, during the entire three-week post challenge period (Table 2). The first fish mortality was noted on the first day after injection in all the test groups, except at the lowest dose. All the fish exposed to $10^{8}$ CFU ml ${ }^{-1}$ of bacteria died within four days of injection. In the group exposed to this highest concentration, the cumulative mortality of C. catla was $25 \%$ on day 1 DPI, $50 \%$ on day 2 DPI, and $100 \%$ on day 4 DPI. No mortalities were observed in the control tank. The median lethal dose $\left(\mathrm{LD}_{50}\right)$ for $C$. catla injected intraperitoneally with $E$. tarda was calculated as $10^{5.5} \mathrm{CFU} \mathrm{ml}{ }^{-1}$.

\section{Clinical and gross signs}

The clinical and gross signs were first visible on day 1 DPI. Briefly, the infected fish showed typical signs of acute septicemia with cutaneous petechial hemorrhages, excessive mucus secretion over the body

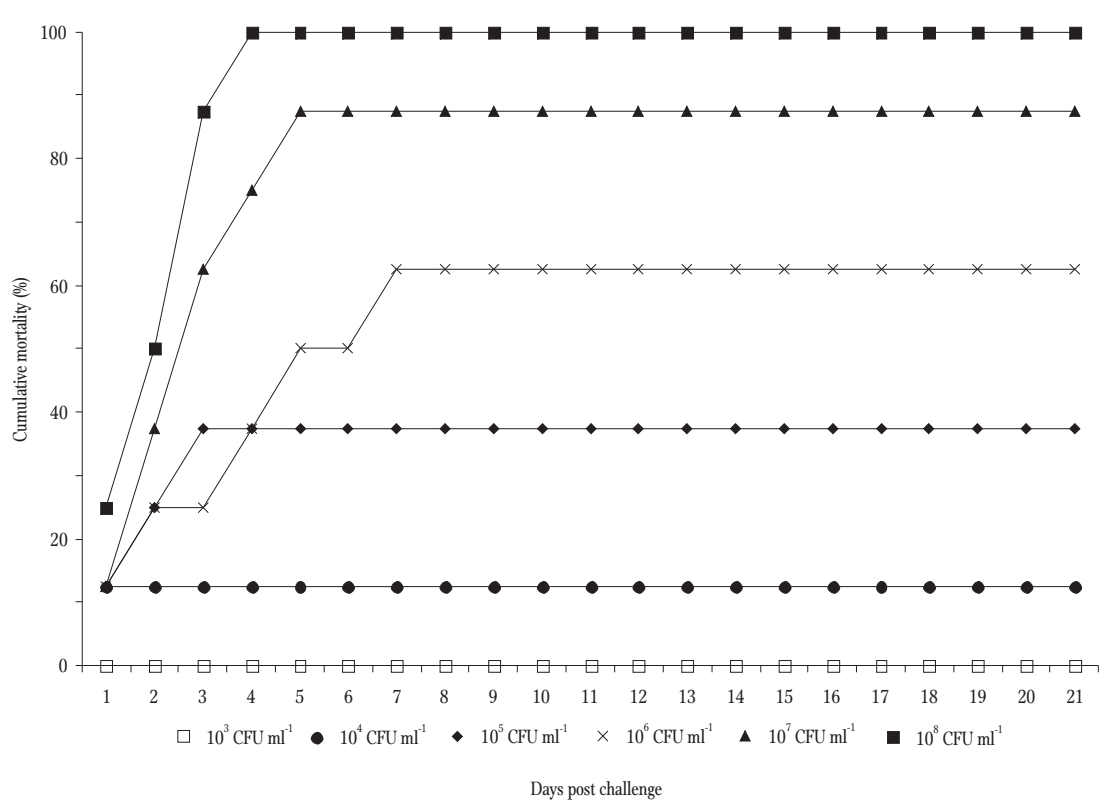

Figure 1. Result of the $\mathrm{LD}_{50}$ test showing cumulative mortality (\%) in C. catla infected intraperitoneally by Edwardsiella tarda at different concentrations. 
Table 2

Summary of $\mathrm{LD}_{50}$ determination experiment. C. catla with body weights of $39.6 \mathrm{~g}$ were intraperitoneally injected with different doses of Edwardsiella tarda and mortality and external clinical signs were recorded for 3 weeks

\begin{tabular}{llllll}
\hline \hline Challenge dose & $\begin{array}{l}\text { Number of fish } \\
\text { injected }\end{array}$ & $\begin{array}{l}\text { Number of fish } \\
\text { died }\end{array}$ & Mortality (\%) & $\begin{array}{l}\text { Fish with external } \\
\text { signs }\end{array}$ & $\begin{array}{l}\text { Fish with external } \\
\text { signs (\%) }\end{array}$ \\
\hline \hline $10^{8}$ & 8 & 8 & 100 & 7 & 100 \\
$10^{7}$ & 8 & 7 & 87.5 & 8 & 100 \\
$10^{6}$ & 8 & 5 & 62.5 & 8 & 100 \\
$10^{5}$ & 8 & 3 & 37.5 & 7 & 87.5 \\
$10^{4}$ & 8 & 1 & 12.5 & 5 & 62.5 \\
$10^{3}$ & 8 & 0 & 0 & 3 & 37.5 \\
\hline \hline
\end{tabular}

surface, and fin erosion (Fig. 2a). In some fish, the injected area showed ulceration with edematous swelling at the injection site. The moribund fish became lethargic, lay on the bottom, and exhibited abdominal dropsy before death. Immediately following death the fish exhibited extensive hemorrhages and hyperemia on the ventral body surface and at the base of the pelvic and pectoral fins. As the disease progressed, abdominal dropsy with yellowish ascetic fluid was observed in some cases (Fig. 2b). Internally, the kidney and liver became enlarged with septicemia changes. There was no mortality in the control group fish during the experiment. Clinical and gross signs were less pronounced after 7 to 8 days DPI and after 10 to 11 days DPI they were absent. The cause of infection was confirmed by the recovery of $E$. tarda on EIA from kidneys.

\section{Histopathological examination}

Different tissues including the kidney, liver, intestine, gill, and heart of the experimentally infected $C$. catla showed major histopathological changes. The kidney showed multi-focal areas of hemorrhage (Fig. 3a) after day 1 DPI. The typical granulomatous structure started to appear from day 4 DPI (Fig. 3b). The catla liver was affected to a lesser degree and only hydropic degeneration in hepatocytes (Fig. 3c)

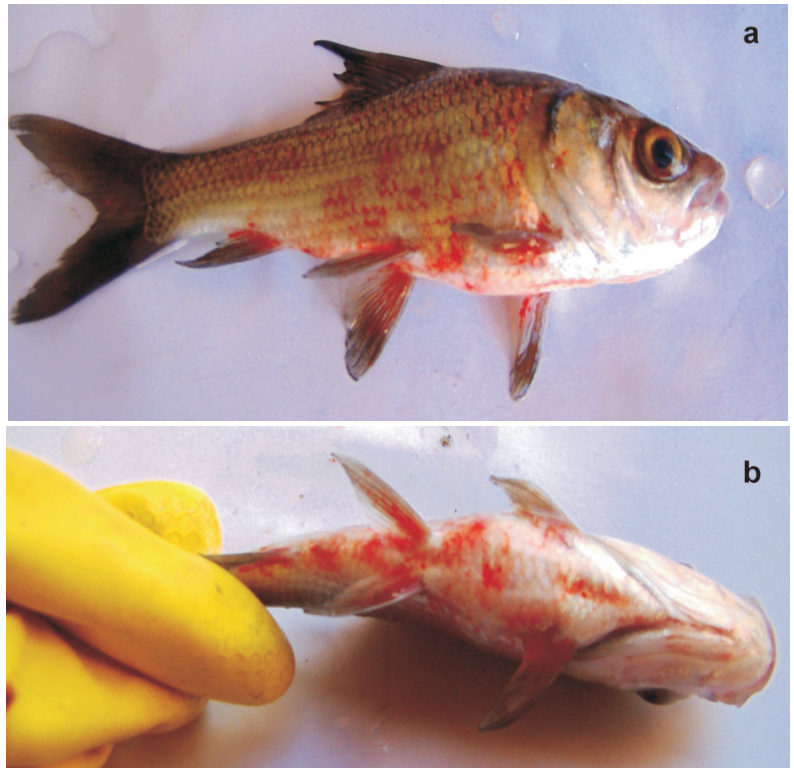

Figure 2. C. catla experimentally infected with E. tarda showing petechial hemorrhages all over the body surface and fin erosion (a), E. tarda infected C. catla with abdominal dropsy (b).

coupled with hyperemic central veins (Fig. 3d) were observed on days one and two DPI, respectively. No granulomatous reaction was observed in the liver. The intestines displayed goblet cell hyperplasia (Fig. 3e) on day 3 DPI. Histopathological findings also showed an inflammatory response in the gills that was associated with cellular infiltration (presumably leucocytes) on day 3 DPI (Fig. 3f). The heart muscle showed cardiac myositis with leucocyte infiltrations on day 2 DPI (Fig. 3g). 

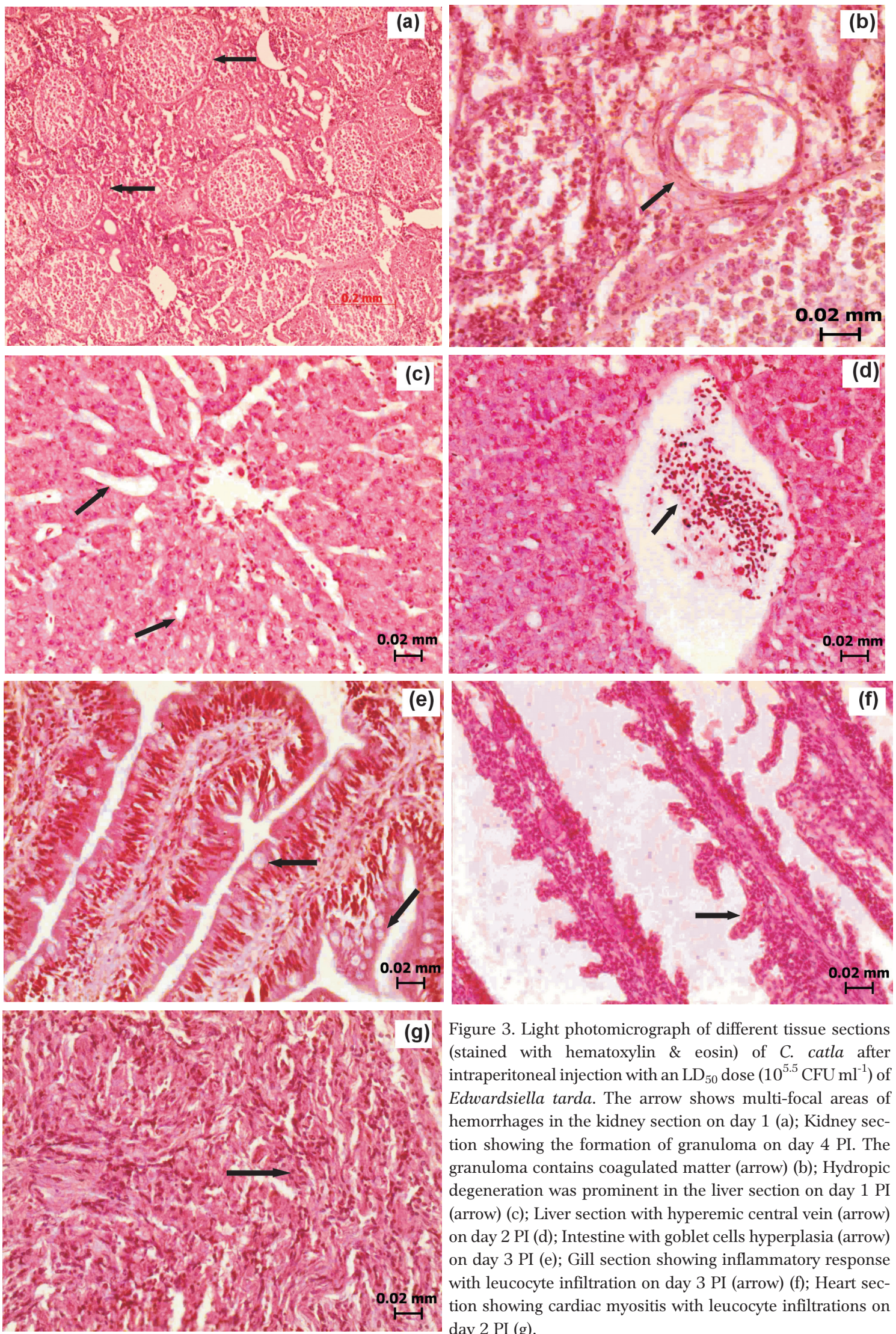

Figure 3. Light photomicrograph of different tissue sections (stained with hematoxylin \& eosin) of C. catla after intraperitoneal injection with an $\mathrm{LD}_{50}$ dose $\left(10^{5.5} \mathrm{CFU} \mathrm{ml}^{-1}\right)$ of Edwardsiella tarda. The arrow shows multi-focal areas of hemorrhages in the kidney section on day 1 (a); Kidney section showing the formation of granuloma on day 4 PI. The granuloma contains coagulated matter (arrow) (b); Hydropic degeneration was prominent in the liver section on day 1 PI (arrow) (c); Liver section with hyperemic central vein (arrow) on day 2 PI (d); Intestine with goblet cells hyperplasia (arrow) on day 3 PI (e); Gill section showing inflammatory response with leucocyte infiltration on day 3 PI (arrow) (f); Heart section showing cardiac myositis with leucocyte infiltrations on day 2 PI (g). 


\section{Discussion}

The present study describes the susceptibility of and the macroscopic and histopathological changes in $C$. catla that were infected experimentally with a virulent strain of E. tarda. Infected C. catla showed typical macroscopic signs of acute septicemia with the occurrence of petechial hemorrhages, abdominal dropsy, other general clinical signs, and septicemic changes in the internal organs. Similar types of clinical signs have also been described in walking catfish, Clarias batrachus (L.) (Sahoo et al. 1998), climbing perch, Anabas testudineus (Bloch) (Sahoo et al. 2000), rohu, L. rohita (Mohanty and Sahoo 2010), African catfish, Clarias gariepnus (Burchell), and Nile tilapia, Oreochromis niloticus (L.) (Ibrahem et al. 2011). However, these clinical signs cannot be considered as pathognomonic for edwardsiellosis. Similar macroscopic signs are frequently observed in other fish bacterial infections. During mild infection, edwardsiellosis is characterized by small cutaneous lesions located on the posterolateral parts of the body. As the disease progresses, abscesses develop in the muscles of the flanks or tail. These abscesses can develop into large cavities filled with gas (Meyer and Bullock 1973). Even though the cutaneous lesions were observed in some of the experimentally infected catla, gas-filled abscess formation was absent. This could have resulted from the rapid course of infection and the small fish size. Similar observations were reported in channel catfish, Ictalurus punctatus (Raf.) infected with E. tarda (Darwish et al. 2000).

Histopathological examination showed significant changes in various tissues that were similar in many ways to those described in other fish species infected by E. tarda. The heart and gill sections examined exhibited signs of cardiac myositis and gill lamellae inflammation associated with leucocyte infiltration. The livers of experimentally infected $C$. catla showed hydropic degeneration coupled with hyperemic central veins. These changes possibly indicated the involvement of inflammatory cells in the response to E. tarda infection. The histopathological alterations are in agreement with those observed in African catfish (Ibrahem et al. 2010, 2011). These necrotic and degenerative changes could be attributed to the potential virulence factors of $E$. tarda.

It is well known that an inflammatory response occurs after a pathogenic invasion of host tissues. Among the different inflammatory cells, macrophages play an important role in inflammatory reactions. In fact, the involvement of macrophages and other leucocytes in mediating strong immune responses in C. catla by the same E. tarda strain are reported in our previous publication (Devi et al. 2012). The responses of macrophages to different diseases such as bacterial kidney disease (Bruno 1986), pasteurellosis (Noya et al. 1995), and edwardsiellosis (Miyazaki and Kaige 1985, Padros et al. 2006) have been described. However, the final expression of these responses could be of different types. For example, the inflammatory response of Japanese eel, Anguilla japonica Temminck \& Schlegel and Japanese flounder, Paralichthys olivaceus (Temminck \& Schlegel) to E. tarda has been described as suppurative (Miyazaki and Kaige 1985, Miyazaki et al. 1992, Padros et al. 2006), whereas other authors described the response of red sea bream, Pagrus major (Temminck \& Schlegel) and tilapia, O. niloticus as granulomatous (Miyazaki and Kaige 1985, Pirarat et al. 2007). These apparent differences in the type of inflammatory response manifested by different species could stem from the fish species itself, the phase of infection, or the virulence factors produced by different strains of E. tarda (Iregui et al. 2012).

The present study showed that the type of inflammation associated with the E. tarda challenge in $C$. catla was similar to that described as granulomatous inflammation by Miyazaki and Kaige (1985). The lesions in the kidney were characterized by the presence of necrotic foci. Initially, inflammatory cells (presumably macrophages) were found to surround the necrotic foci in an early stage of the granulomatous response. As the infection progressed, layered epithelioid cells walled off the necrotic area containing affected tissue, inflammatory 
cells and bacterial cells, resulting in the formation of granulomas. As observed in the present study, granulomas commonly contained coagulated to caseated matter similar to that observed in tilapia after E. tarda infection (Miyazaki and Kaige 1985).

\section{Conclusion}

In conclusion, this is the first study on the susceptibility and pathological changes of $C$. catla against $E$. tarda infection. The pathological signs and symptoms were typical for edwardsiellosis. Histopathological evidence indicated that the inflammation type following induced edwardsiellosis in fingerlings of $C$. catla $\quad(<50 \mathrm{~g}$ size $)$ was granulomatous in nature. Thus, the study confirmed the susceptibility of $C$. catla to $E$. tarda infection and that this bacterium poses a threat to $C$. catla farming. Intraperitoneal injection is generally considered to be a reliable, quick, and easy challenge method. However, as this method allows bacteria to directly invade the intraperitoneal cavity, the role of anatomical barriers such as skin and mucus is bypassed (Itano et al. 2006). Thus, it is necessary to study a more natural route of infection like waterborne transmission in order to fully understand the pathological consequences for C. catla.

Acknowledgments. The authors are thankful to the Vice Chancellor, Central Agricultural University and Dean, College of Fisheries, CAU, Lembucherra, Tripura, for providing the necessary research facilities.

Author contributions. D.K. designed the experiment, analysed the data, and wrote the paper; T.B.D. performed the experiments, arranged the data, and conducted the literature review; T.J.A. isolated and identified the test bacterium and reviewed the article.

\section{References}

Austin B., Austin D. A. 2007 - Bacterial Fish Pathogens: Diseases of farmed and wild fish - Springer-Praxis, Godalming, UK, 552 p.
Bruno D.W. 1986 - Histopathology of bacterial kidney disease in laboratory infected rainbow trout, Salmo gairdneri Richardson, and Atlantic salmon, Salmo salar L., with reference to naturally infected fish - J. Fish Dis. 9: 523-537.

Darwish A., Plumb J.A., Newton J.C. 2000 - Histopathology and pathogenesis of experimental infection with Edwardsiella tarda in channel catfish - J. Aquat. Anim. Health 12: 255-266.

Devi T.B., Kamilya D., Abraham T.J. 2012 - Dynamic changes in immune-effector activities of Indian major carp, catla (Catla catla) infected with Edwardsiella tarda - Aquaculture 366-367: 62-66.

Fisheries and Oceans Canada 2004 - Fish Health Protection Regulations: Manual of compliance - Fisheries and Marine Service, Miscellaneous Special Publications 31 (Revised) Canada.

Herman R.L., Bullock G.L. 1986 - Pathology caused by the bacterium Edwardsiella tarda in striped bass - T. Am. Fish. Soc. 115: 232-235.

Ibrahem M. D., Atta A.H., Shalaby M.A. 2010 Bioavailability of Orbifloxacin in African sharptooth catfish, Clarias gariepinus, and its efficacy in control of induced Edwardsiellosis - J. Am. Sci. 6: 236-244.

Ibrahem M.D., Shaheed B., Yazeed H.A.E., Korani H. 2011 Assessment of the susceptibility of polyculture reared African catfish and Nile tilapia to Edwardsiella tarda - J. Am. Sci. 7: 779-786.

Iregui C.A., Guarin M., Tibata V.M., Ferguson H.W. 2012 Novel brain lesions caused by Edwardsiella tarda in a red tilapia (Oreochromis spp.) - J. Vet. Diagn. Invest. 24: 446-449.

Itano T., Kawakami H., Kono T., Sakai M. 2006 - Experimental induction of nocardiosis in yellowtail, Seriola quinqueradiata Temminck \& Schlegel by artificial challenge - J. Fish Dis. 29: 529-534.

Lakshman M., Devivaraprasad R. A., Khuntia B.K., Udgata S.K., Rath R.K. 2015 - Qualitative and quantitative changes of fried fish steaks and fish steak curry of catla (Catla catla) during frozen storage - Int. Food Res. J. 22: 2057-2067.

MacFaddin J.F. 1980 - Biochemical Tests for Identification of Medical Bacteria - Williams and Wilkins, Baltimore, USA, 527 p.

Meyer F.P., Bullock G.L. 1973 - Edwardsiella tarda, a new pathogen of channel catfish (Ictalurus punctatus) - Appl. Microbiol. 25: 155-156.

Miyazaki T., Gutierrez M.A., Tanaka S. 1992 - Experimental infection of edwardsiellosis in the Japanese eel - Fish Pathol. 27:39-47.

Miyazaki T., Kaige N. 1985 - Comparative histopathology of edwardsiellosis in fishes - Fish Pathol. 20: 219-227.

Mohanty B.R., Sahoo P.K. 2007 - Edwardsiellosis in fish: a brief review - J. Biosci. 32: 1331-1344. 
Mohanty B.R., Sahoo P.K. 2010 - Immune responses and expression profiles of some immune-related genes in Indian major carp, Labeo rohita to Edwardsiella tarda infection - Fish Shellfish Immunol. 28: 613-621.

Noya M., Magarińos B., Toranzo A.E., Lamas J. 1995 - Sequential pathology of experimental pasteurellosis in gilthead seabream Sparus aurata. A light and electron-microscopic study - Dis. Aquat. Org. 21: 177-186.

Padros F., Zarza C., Dopazo L., Cuadrado M., Crespo S. 2006 - Pathology of Edwardsiella tarda infection in turbot, Scophthalmus maximus (L.) - J. Fish Dis. 29: 87-94.

Pirarat N., Maita M., Endo M., Katagiri T. 2007 - Lymphoid apoptosis in Edwardsiella tarda septicemia in tilapia, Oreochromis niloticus - Fish Shellfish Immunol. 22: 608-616.

Plumb J.A. 1993 - Edwardsiella Septicaemia - In: Bacterial diseases of fish (Eds) V. Inglis, R.J. Roberts, N.R. Bromage, Blackwell, Oxford: 61-79.

Plumb J. A. 1999 - Edwardsiella septicaemias - In: Fish diseases and disorders, volume 3: viral, bacterial, and fungal infections (Eds) P.T.K. Woo, D.W. Bruno, CAB International, Oxon: 479-521.

Presnell J.K., Schreibman M. 1997 - Humason's animal tissue techniques - Johns Hopkins University Press, Baltimore, USA, $572 \mathrm{p}$.

Rao S.P.S., Lim T.M., Leung K.Y. 2001 - Opsonized virulent Edwardsiella tarda strains are able to adhere to and survive and replicate within fish phagocytes but fail to stimulate reactive oxygen intermediates - Infect. Immun. 69: 5689-5697.
Reddy P.V.G.K. 1999 - Genetic resources of Indian major carps - FAO Fisheries Technical Paper No. 387, Rome.

Reed L.J., Muench H.A. 1938 - Simple method of estimating fifty per cent endpoints - Am. J. Hyg. 27: 493-497.

Sahoo P.K., Mukherjee S.C., Sahoo S.K. 1998 - Aeromonas hydrophila versus Edwardsiella tarda: A pathoanatomical study in Clarias batrachus - J. Aquac. 6: 57-66.

Sahoo P.K., Swain P., Sahoo S.K., Mukherjee S.C., Sahu A.K. 2000 - Pathology caused by the bacterium Edwarsiella tarda in Anabas testudineus (Bloch) - Asian Fish. Sci. 13: 357-362.

Shetty M., Maiti B., Venugopal M.N., Karunasagar I., Karunasagar I. 2014 - First isolation and characterization of Edwardsiella tarda from diseased striped catfish, Pangasianodon hypophthalmus (Sauvage) - J. Fish Dis. 37: 265-271.

Shotts E.B., Waltman II W.D. 1990 - A medium for the selective isolation of Edwardsiella ictaluri - J. Wildl. Dis. 26: 214-218.

Swain P., Nayak S.K. 2003 - Comparative sensitivity of different serological tests for seromonitoring and surveillance of Edwardsiella tarda infection of Indian major carps - Fish Shellfish Immunol. 15: 333-340.

Xiao J., Wang Q., Liu Q., Wang X., Liu H., Zhang Y. 2009 Isolation and identification of fish pathogen Edwardsiella tarda from mariculture in China - Aquac. Res. 40: 13-17. 